\title{
Flamingo mortality due to collision with high tension electric wires in Gujarat, India
}

\author{
Anika Tere ${ }^{1} \&$ B.M. Parasharya ${ }^{2}$ \\ 1,2 AINP on Agricultural Ornithology, Biological Control Laboratory Building, Anand Agricultural University, Anand, Gujarat 388110, \\ India \\ ${ }^{1}$ Present address: Zoology Department, Faculty of Science, M.S. University of Baroda, Vadodara, Gujarat 390002, India \\ Email: ${ }^{1}$ anikatere@rediffmail.com, ${ }^{2}$ parasharya@yahoo.com (corresponding author)
}

Date of publication (online): 26 November 2011 Date of publication (print): 26 November 2011 ISSN 0974-7907 (online) | 0974-7893 (print)

Editor: C. Srinivasulu

\section{Manuscript details:}

Ms \# 01689

Received 07 December 2006

Final received 17 June 2011

Finally accepted 14 October 2011

Citation: Tere, A. \& B.M. Parasharya (2011) Flamingo mortality due to collision with high tension electric wires in Gujarat, India. Journal of Threatened Taxa 3(11): 2192-2201.

Copyright: (C) Anika Tere \& B.M. Parasharya 2011. Creative Commons Attribution 3.0 Unported License. JoTT allows unrestricted use of this article in any medium for non-profit purposes, reproduction and distribution by providing adequate credit to the authors and the source of publication.

Author Details: see end of this article.

Author contribution: This study is a part of the PhD thesis of Anika Tere. AT and BMP did extensive field surveys and recorded this information. AT prepared the map and compiled data, BMP prepared the manuscript.

Acknowledgements: We are thankful to the Department of Space, Government of India for providing funds to carry out research on flamingos. We are grateful to the authority of Border Security Force for permitting us to enter and study in the border area and entire staff for their kind hospitality. We thank to the Department of Forest, Government of Gujarat for their permission to enter into the sanctuary areas. We appreciate the help of the birdwatchers, particularly, Shri S.N. Varu, Ghanshyam Jebalia, Jummabhai Moria, Kishor Joshi, Jaidev Nancy, Amin Sama, Viral Prajapati and Bhikhabhai Paredhi for their information. We are thankful to Mr. Sejwan of Border Security Force, Gujarat Frontier for providing necessary information about flamingo mortality in border area of Great Rann.
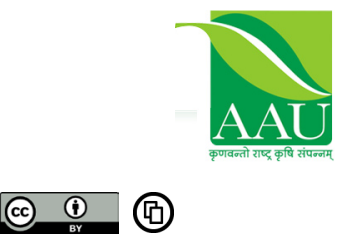

OPEN ACCESS | FREE DOWNLOAD
Abstract: This study documents the mortality of flamingos due to collision with electric wires in the state of Gujarat, India. The wetlands of Gujarat were surveyed from 2002 to 2005 as a part of ecological studies on flamingos. Incidences of collision of flamingos with overhead electric wires were recorded at breeding and feeding sites. The numbers of victim birds were counted and high risk sites were identified based on reported incidences of collision and the period of inundation of the sites below electric lines. Of the 76 deaths recorded, Lesser Flamingos Phoeniconaias minor (46\%) and Greater Flamingos Phoenicopterus roseus (54\%) accounted almost equally. The effects of collision on the population of flamingos and the management options to minimize collision of flamingos and other water birds with electric lines in sensitive habitats are discussed.

Keywords: Breeding ground, feeding ground, Greater Flamingo, Lesser Flamingo, mortality, Phoeniconaias minor, Phoenicopterus roseus, saltpans, sewage pond.

\section{INTRODUCTION}

Power lines, telephone lines and other utility structures have become an inseparable part of our modern life. Establishment and coverage of utility structures has increased with the development of modern and advanced life. As a result, the interaction of birds with utility structures has come into the picture. Birds use power lines and telephone lines for roosting, nest building and prey surveillance (Bevanger 1990). Power lines passing through areas with a high concentration of birds e.g. roosting and feeding places, create an extremely high collision risk and this is one of the important factors negatively affecting the bird population. Wirestrikes can occur at any place where the combination of overhead wires and birds exists (Bevanger 1990).

Collision with power lines is considered an important cause of death for some species of birds (McNeil et al. 1985; Crivelli et al. 1988; Morkill \& Anderson 1991; Parasharya et al. 2000; Sundar \& Choudhury 2005). For most species involved in collisions, however, the death rate at the population level is low (Beaulaurier 1981; Faanes 1987; Brown 1993; Hugie et al. 1993). However, power-line mortality for threatened species can be an important concern for wildlife managers (Janss \& Ferrer 1998; McCann \& Rooyen 2002; Sundar \& Choudhury 2005).

Flamingos are habitat specialists and hence destruction or alteration of habitat is considered a serious threat to their population. Collision of flamingos with electric lines is identified as a threat (Longridge 1986; Parasharya \& Tere 2006; Johnson \& Cezilly 2007), having local significance (Childress et al. 2008) on the population. 
India being a highly populated country, development is taking place even in remote areas (including Rann of Kachchh which is a breeding ground for flamingos). The mortality of flamingos due to collision with electric wires is of local significance but it needs to be minimized. Except for a serious study on the effect of collision on the Sarus Crane Grus antigone population (Sundar \& Choudhury 2005), no detailed study has been done on any of the threatened bird species in India.

To avoid collision of birds with overhead wires and to propose an appropriate remedial action plan, it is necessary to understand where the collisions take place more frequently (Bevanger 1990, 1993). The two species of flamingos, namely, Greater Flamingo Phoenicopterus roseus and Lesser Flamingo Phoeniconaias minor, are resident in India (Ali \& Ripley 1983); the Lesser Flamingo is also considered a globally Near Threatened species (BirdLife International 2008a). The flamingos have often been seen as victims of collisions with the electric wires in Gujarat, India (Kishor Joshi, S.N. Varu, Ghanshyam Jebalia, Viral Prajapati, G.M. Sejvan pers. comm.); but the information remained unnoticed due to a lack of awareness and non-reporting of the incidences. The main objective of this paper is to identify the sites of flamingo collision with electric lines and telephone lines (utility structures) in Gujarat, India and to discuss possible solutions to mitigate the same.

\section{STUDY AREA}

Little Rann and Great Rann of Kachchh are regular breeding sites of flamingos (Ali 1960, 1974; Parasharya \& Tere 2006) in Gujarat State, India. Both species of flamingos congregate in the Rann of Kachchh for breeding once the Rann gets inundated by the southwest monsoon (Tere 2005).

Hence, for convenience, all the wetlands of Gujarat were broadly divided into (i) Breeding sites: Rann of Kachchh (Little Rann and Great Rann) and (ii) Feeding sites: The coastal wetlands (sea coast, mud flats, salt pans, fresh water tanks or sewage within $10 \mathrm{~km}$ of the sea coast) on the Gulf of Kachchh, Gulf of Khambhat (Cambay) and other coastal sites of Saurashtra region. The inland wetlands are utilized as feeding sites particularly during the post-breeding (summer) season. For additional details of the study sites refer to Jadhav \& Parasharya (2004). The sites of collision are marked with a solid square ( $\square)$ on Figure 1 of the study area.

\section{METHODS}

The wetlands of Gujarat, India, holding a considerable population of flamingos were surveyed from August 2002 to December 2005 during a study on the ecology of flamingos. The breeding sites were surveyed after their inundation by the south-west monsoon (June-September). Incidences of flamingo mortality due to collision with electric wires and the number of victim birds were recorded and the collision sites were identified. Coordinates of the collision sites were taken using a GPS and later determined using Google maps. Habitat conditions (inundation/dry) were noted at the site of collision. Close observation of the bodies of the dead birds was done wherever possible, to know the type of injury and the probable time of the accidents. The probable time of the accident (fresh or old) of the dead birds was estimated on the basis of their relative body warmth, feather condition and the condition of tissue (fresh/ decomposed).

No intensive search was done below the power line to record flamingo mortality due to collision with wires. The incidences of collision recorded here are all casual records made while driving on the road and when the power line was running parallel to the road.

The information regarding their collision with electric power lines was also gathered from Border Security Force personnel and birdwatchers distributed throughout the state, when the sites could not be visited personally. High-risk areas were identified based on repeated incidences of collision and the period of inundation of the wetlands below the electric lines.

Two types of wire network were considered: Power lines and Telephone lines.

\section{Power Lines}

Two kinds of power lines were differentiated during the study: (i) supply wires or distribution lines consisting of two parallel wires made of steelreinforced aluminium wires of $52.21-103.6 \mathrm{~mm}^{2}$ at a height of $5.8 \mathrm{~m}$ from the ground carrying $200-400 \mathrm{~V}$ electricity (referred to as supply wires throughout the 


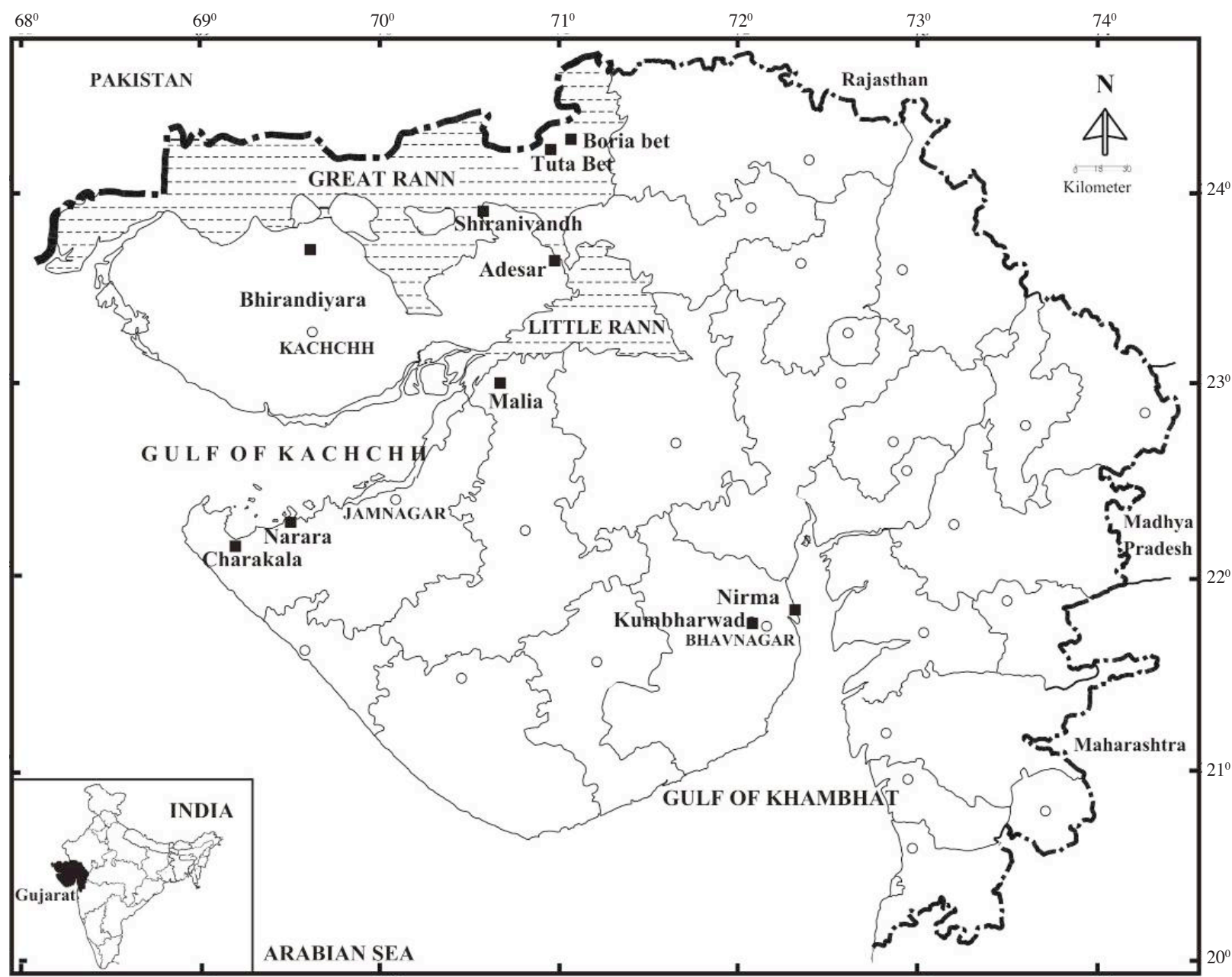

Figure 1. Sites of regular flamingos collisions in Gujarat State, India, marked as solid square ( $\square$ ).

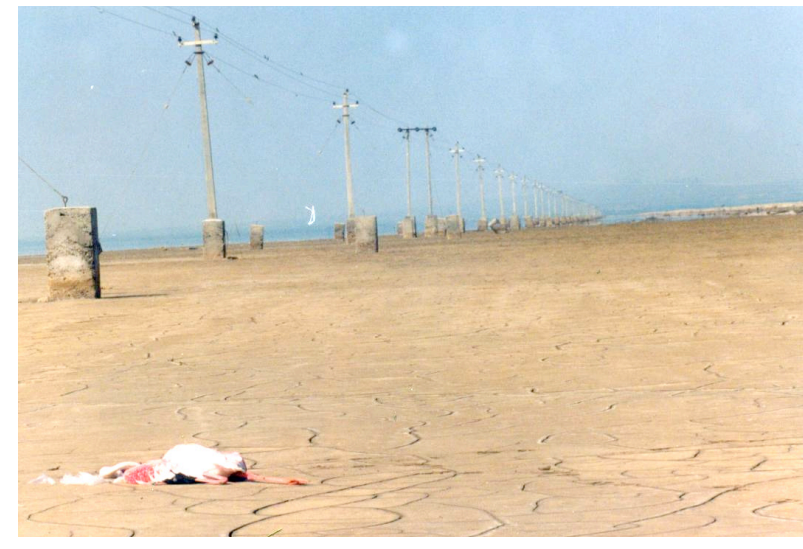

Image 1. Collision of Lesser Flamingo with distribution line at Shiranivandh

paper; Image 1). The distribution lines were supported by a small single pole; (ii) High tension power lines or Transmission lines (Image 2) consisted of three sets of parallel wires and a top earth wire of $207 \mathrm{~mm}^{2}$

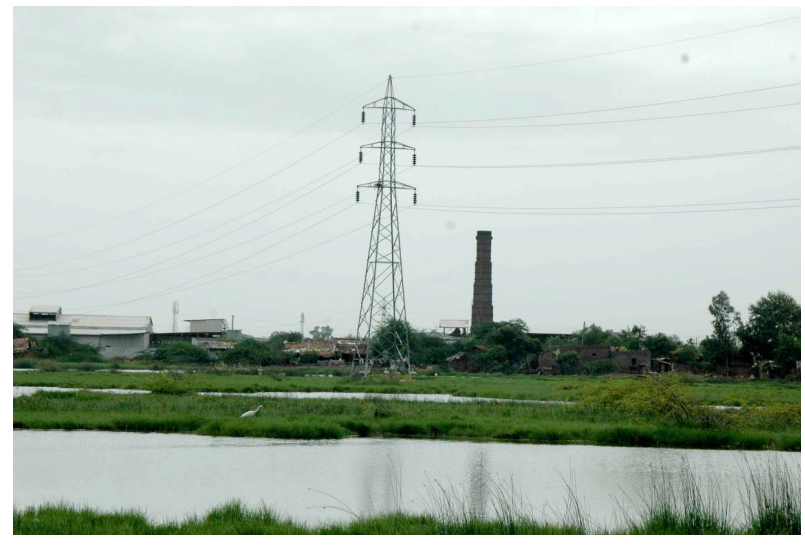

Image 2. Transmission line across wetland at Kumbharwada, Bhavnagar. Note thin earthing wire on top

steel-reinforced aluminium, with the lowest set $6.1 \mathrm{~m}$ from the ground and the terminating ground wire 10$12 \mathrm{~m}$ from the ground, and carrying $11000-13500 \mathrm{~V}$ electricity (Sundar \& Choudhury 2005; referred to as 


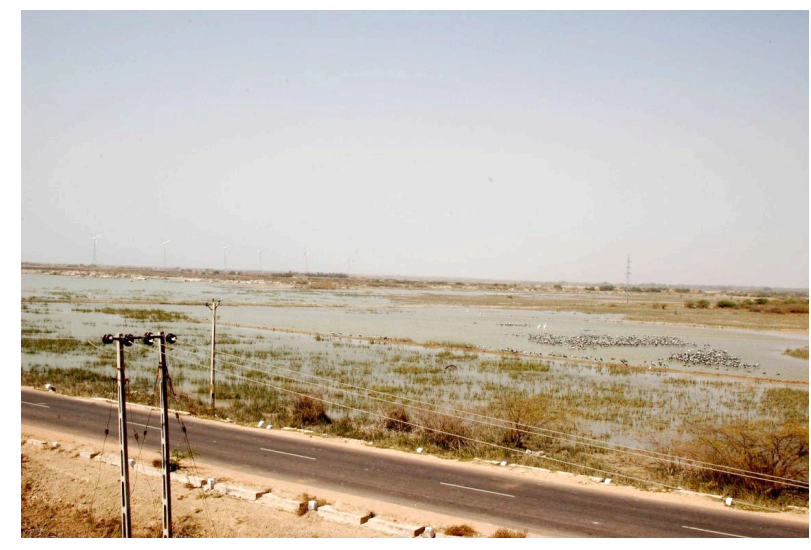

Image 3. Distribution line, telephone line and transmission line across a wetland.

power lines throughout the paper). The transmission lines were supported on giant structures. These specifications of electric lines were almost the same throughout the state. The height of the wires from the ground varied to some extent.

\section{Telephone Wires}

Telephone wires, usually a pair, were fixed at a height of $6.0 \mathrm{~m}$ above the ground. Such wiring was responsible for collision at only one place. At some sites, both electric lines and telephone lines crossed a wetland (Image 3).

\section{RESULTS}

Incidences of flamingos' colliding with electric power lines and telephone lines (utility structures) were recorded both at breeding and feeding sites in Gujarat, India. The detailed account is as follows:

\section{(A) Collision at the breeding sites}

The collision of flamingos was noticed at four sites in the Great Rann of Kachchh, namely, (i) The area around Boria and Tuta Beyt in the eastern part of the Great Rann; (ii) in the Rann between Shiranivandh Amarapar in Rapar Tahsil of Kachchh; (iii) Vekariodhandh near Bhirandiyara, between Bhuj and Khavda and (iv) Rann area near Adesar, on the boundary of Patan and Kachchh districts, which also separates inundated areas of the Little Rann and the Great Rann (Fig. 1). The flamingos gather at / around these sites during their breeding season, after the Rann was inundated during the south-west monsoon (JuneSeptember).

On 13 December 2003, two Greater Flamingos and three Lesser Flamingos were recorded dead after collision with telephone wires in the northeastern part of the Great Rann of Kachchh, between Tuta and Boria beyt (Table 1). Personnel of the Border Security Force (BSF) reported that several flamingos were found dead below the telephone wires during September to December 2003 when the area was inundated. The BSF personnel had also seen such casualties on the same route in the year 2004 as well as in 2005 (G.M. Sejvan pers. comm.). After 2005, two parallel electric lines were established along the length of the telephone line from the mainland to the international border which has further increased the incidences of mortality during the monsoons (G.M. Sejwan pers. comm.). These three lines run parallel to a road transecting the inundated Rann for about $45 \mathrm{~km}$. This area is very close to the recently discovered nesting site of flamingos (Parasharya \& Tere 2006).

At Shiranivandh, the power line (distribution line at low height) runs parallel to the $10 \mathrm{~km}$ long bridge constructed across the inundated Rann connecting the former with Khadir Island (Beyt). During October 2003, the area on either side of this road was inundated. A total of 600,000 Lesser Flamingos and 20,000 Greater Flamingos were counted in this inundated area. On 23 October 2003, when we were observing the flamingos we saw two domestic dogs chasing them in shallow water at the other end. All the flamingos close to the dogs flew away but one which struggled to stand and take off. We rescued it and realized that its right wing was severely damaged and had a wound on the upper surface. A total of eight Lesser Flamingos were recorded dead due to collision with the overhead power lines along the road during a five day period (Table 1). Freshly collided flamingos were recorded during the morning hours, suggesting that the flamingos collided with the wire during the low light hours (Image 1).

A total of 26 Greater Flamingos were recorded dead in Rann, adjacent to the state highway joining Patan District with Kachchh near Adesar on 24 October 2003. An incidence of flamingo collision with an electric line was again recorded on 13 October 2005 at the same site (Table 1). Local people reported that flamingos die at this site every year after habitat inundation. This 
Table 1. Collision of flamingos with power and telephone lines in Gujarat

\begin{tabular}{|c|c|c|c|c|c|c|}
\hline & Date & Place & Coordinates & $\begin{array}{c}\text { Bird } \\
\text { species }\end{array}$ & $\begin{array}{l}\text { No. of } \\
\text { deaths }\end{array}$ & $\begin{array}{l}\text { Overhead wire } \\
\text { type }\end{array}$ \\
\hline \multicolumn{7}{|c|}{ Breeding and feeding sites } \\
\hline 1 & 19.x.2003 & Shiranivandh: GRK & 23⒌'29.632"N \& 70³2'32.624"E & LF & 3 & Distribution line \\
\hline 2 & 23.x.2003 & Shiranivandh: GRK & 23054'29.632"N \& 70³2'32.624"E & LF & 5 & Distribution line \\
\hline 3 & 24.x.2003 & Nr. Adesar, Patan-Kachchh Boundary & $23^{\circ} 37^{\prime} 33.867^{\prime \prime} \mathrm{N} \& 7^{\circ} 02^{\prime} 56.085^{\prime \prime} \mathrm{E}$ & GF & 26 & Transmission line \\
\hline 4 & 13.xii.2003 & Between Boria Bet and Tuta Bet, GRK & $24^{0} 17^{\prime} 2.70^{\prime \prime} \mathrm{N} \& 71^{\circ} 0^{\prime} 36.60^{\prime \prime} \mathrm{E}$ & GF & 2 & Telephone line \\
\hline 5 & 13.xii.2003 & Between Boria Bet \& Tuta Bet, GRK & 24017'35.28”N \& 7101'11.64"E & LF & 3 & Telephone line \\
\hline 6 & 14.i.2004 & $\begin{array}{l}\text { Near Bhirandiyara, } 50 \mathrm{~km} \text { north to } \\
\text { Bhuj, GRK *1 }\end{array}$ & $23^{\circ} 32^{\prime} 2.28^{\prime \prime} \mathrm{N} \& 69^{\circ} 40^{\prime} 4.62^{\prime \prime} \mathrm{E}$ & GF & 7 & Transmission line \\
\hline 7 & 14.ii.2004 & $\begin{array}{l}\text { Near Bhirandiyara, } 50 \mathrm{~km} \text { north to } \\
\text { Bhuj, GRK }\end{array}$ & $23^{\circ} 32^{\prime} 2.28^{\prime \prime} \mathrm{N} \& 69^{\circ} 40^{\prime} 4.62^{\prime \prime} \mathrm{E}$ & GF & 2 & Transmission line \\
\hline 8 & 02.vii.2004 & Malia Salt Pans, Kachchh & 23011'27.796”"N \& 7043’09.567"E & LF & 1 & Transmission line \\
\hline 9 & 04.vii.2005 & Malia Salt Pans, Kachchh & $23^{0} 11^{\prime} 27.796 " N \& 0^{\circ} 43^{\prime} 09.567^{\prime \prime} \mathrm{E}$ & LF & 2 & Transmission line \\
\hline 10 & 13.x.2005 & Nr. Adesar, Patan-Kachchh Boundary & $23^{\circ} 37^{\prime} 33.867^{\prime \prime} N \& 7^{\circ} 02^{\prime} 56.085^{\prime \prime} \mathrm{E}$ & GF & 3 & Transmission line \\
\hline \multicolumn{7}{|c|}{ Feeding sites } \\
\hline 11 & 27.viii.2002 & Nirma Salt Pans, Bhavnagar & $21^{0} 54^{\prime} 02.902^{\prime \prime} \mathrm{N} \& 72^{\circ} 10^{\prime} 27.508^{\prime \prime} \mathrm{E}$ & GF & 1 & Distribution line \\
\hline 12 & 06.xi.2002 & Kumbharwada, Bhavnagar & $21^{\circ} 46^{\prime} 45.685^{\prime \prime} N \& 2^{\circ} 06^{\prime} 28.144^{\prime \prime} E$ & LF & 1 & Transmission line \\
\hline 13 & 26.i.2003 & Nirma Salt Pans, Bhavnagar & $21^{\circ} 46^{\prime} 45.685^{\prime \prime} \mathrm{N} \& 72^{\circ} 06^{\prime} 28.144^{\prime \prime} \mathrm{E}$ & LF & 1 & Distribution line \\
\hline 14 & $27 . x .2003$ & Kumbharwada, Bhavnagar & $21^{\circ} 46^{\prime} 45.685^{\prime \prime} \mathrm{N} \& 72^{\circ} 06^{\prime} 28.144^{\prime \prime} \mathrm{E}$ & LF & 1 & Transmission line \\
\hline 15 & 14.xi.2004 & Kumbharwada, Bhavnagar & $21^{\circ} 46^{\prime} 45.685^{\prime \prime} \mathrm{N} \& 7^{\circ} 06^{\prime} 28.144^{\prime \prime} \mathrm{E}$ & LF & 1 & Transmission line \\
\hline 16 & 02.xi.2005 & Kumbharwada, Bhavnagar & $21^{\circ} 46^{\prime} 45.685^{\prime \prime} \mathrm{N} \& 72^{\circ} 06^{\prime} 28.144^{\prime \prime} \mathrm{E}$ & LF & 1 & Transmission line \\
\hline 17 & Jan 2004 & Charakala Salt Pans, Jamnagar ${ }^{\star 2,3}$ & $22^{0} 11^{\prime} 50.75^{\prime \prime} \mathrm{N} \& 69^{\circ} 8^{\prime} 37.13^{\prime \prime} \mathrm{E}$ & LF & 16 & Distribution line \\
\hline
\end{tabular}

GF - Greater Flamingo; LF - Lesser Flamingo; GRK - Great Rann of Kachchh

${ }^{{ }^{*} 1}$ - Data collected from Shri Shantilal Varu; ${ }^{{ }^{2}}$ - Shri Ghanshyam Jebalia; ${ }^{{ }^{*}}$ - Jummabhai Moria

site was about $19 \mathrm{~km}$ west of Santalpur and had huge electric poles with three pairs of overhead transmission wires. The birds flying between Little Rann and Great Rann have to cross this corridor and hence the risk of collision is very high in this $5-\mathrm{km}$ stretch. Moreover, near Adesar, there is a water body spread over a $2.5 \mathrm{~km}^{2}$ area, parallel to the road and just below two parallel transmission lines (Image 4). Both species of flamingos feeding in this wetland are at very high risk of collision as they are often disturbed by vehicular traffic on the road.

Two incidences of collision were recorded at Vekariodhandh near Bhirandiyara, 50km north of Bhuj, on the Bhuj-Khavda road in Kachchh (Fig. 1, Table 1). On 14 January 2004, seven Greater Flamingos were found dead due to collision with the electric wire at this site (S.N. Varu pers. comm.). On 14 February 2004, two more dead Greater Flamingos were found at the same site in the morning hours. The bodies were slightly warm and not disturbed by predators. Such collisions are frequent at this particular site (Amin

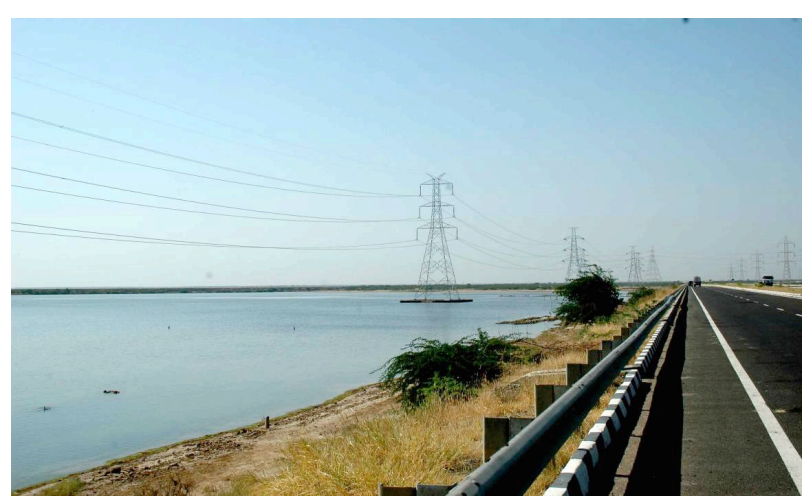

Image 4. Two parallel transmission line between Little Rann and Great Rann near Adesar, Kachchh.

Sama pers. comm.) every year during the monsoon and winter.

In the first weeks of July 2004 and 2005, one Lesser Flamingo was found dead after collision with electric transmission wires in a salt pan area at Malia (Fig.1, Table 1). Huge electric transmission lines run parallel to the salt pans and cross the Hadakia Creek at Surajbari 


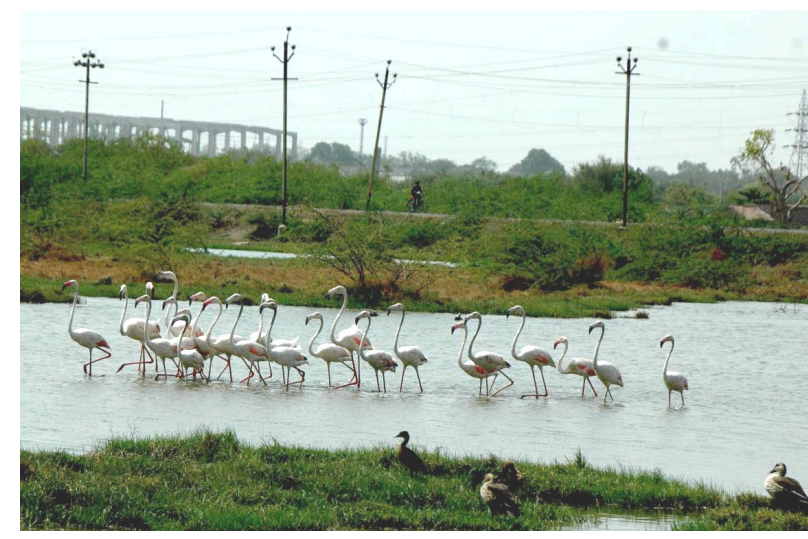

Image 5. Risk of collision with distribution line at Bhavnagar.

Bridge, which is the entrance site for flamingos from the Gulf of Kachchh into their breeding ground, the Rann of Kachchh.

\section{(B) Collision at the feeding sites}

During the non-breeding and post-breeding periods, both the species are largely restricted to the coastal wetlands (Jadhav \& Parasharya 2004; Tere \& Parasharya 2005) with a small population at the inland Wetlands.

The collision of flamingos with electric lines was noticed repeatedly at Nirma salt pans (ca. $35 \mathrm{~km}^{2}$ area) and Kumbharwada sewage pond in Bhavnagar District during the study period (Table 1, Images 2, 5). The collisions at these sites are so frequent, that the local fishermen have learnt to scan areas with overhead wires and collect the birds for consumption (Mundkur 1997; present study). Both the sites remain inundated permanently and serve as feeding grounds for both the species of flamingos throughout the year (Tere 2005; Tere \& Parasharya 2005).

A total of 16 Lesser Flamingos died due to collision with distribution wires at the Charakala salt pans (Tata Chemicals, Mithapur) of Jamnagar District in January 2004. Charakala salt pans are spread over a vast area (ca. $40 \mathrm{~km}^{2}$ area) and support a large number of water birds along with both species of flamingos. Flamingo mortality due to collision with electric wires was also noticed at salt pans around Narara of Jamnagar District (Jummabhai Moria, pers. comm.)

\section{DISCUSSION}

At all the sites the overhead wires are $\geq 20$ feet above the ground and are within or near the feeding sites of flamingos. At many sites the overhead electric transmission wires run along with a single very thin non-transformer wire (neutral wire) which appears to be more hazardous. The reason for the collision of flamingos is the invisibility of the overhead wires and the paucity of time to make avoidance manoeuvres. Flamingos are known to fly at night and under poor light conditions (Ogilvie \& Ogilvie 1986; Johnson \& Cezilly 2007). Freshly dead flamingos were recorded during the morning hours suggesting that these overhead wires are not visible during the night and the dark hours of late evening or early morning.

Repeated incidents of mortality due to collision with wires were recorded at Boria and Tuta Beyt (eastern part of Great Rann), Adesar, Shiranivandh and Bhirandiyara which are very close to the breeding grounds of flamingos. The northern fringe of the Rann of Kachchh forms the international border with Pakistan. Along the border one can see the presence of barbed wire to guard the border and an electric line passes through for supply of electricity to the fringe villages. The fencing and electric lines often transect the inundated Rann during the monsoon. Once, a soldier narrated an incidence of flamingos getting trapped in the barbed wire fencing on the international border.

A juvenile of Common Crane Grus grus was observed dead due to collision at Vekariodhandh near Bhirandiyara along with Greater Flamingos on 14 February 2004. Other birds such as Ruff Philomachus pugnax, Gull-billed Tern Gelochelidon nilotica were also recorded dying along with the flamingos due to collision with electric wires at Nirma salt pans of Bhavnagar during the study period. However, the deaths of small birds go unnoticed due to their size. Sarus Crane Grus antigone have been reported dying due to collision with electric wires at the wetlands of Kheda District, Gujarat (Parasharya et al. 2000; Mukherjee et al. 2002) and Uttar Pradesh (Sundar \& Choudhury 2005). The Great White Pelican Pelecanus onocrotalus has been a victim of such wires at Nanda Beyt bet, in the Little Rann of Kachchh during its inundation in October 2005 (Bhikhabhai Paredhi pers. comm.). The Dalmatian Pelicans (Vulnerable; 


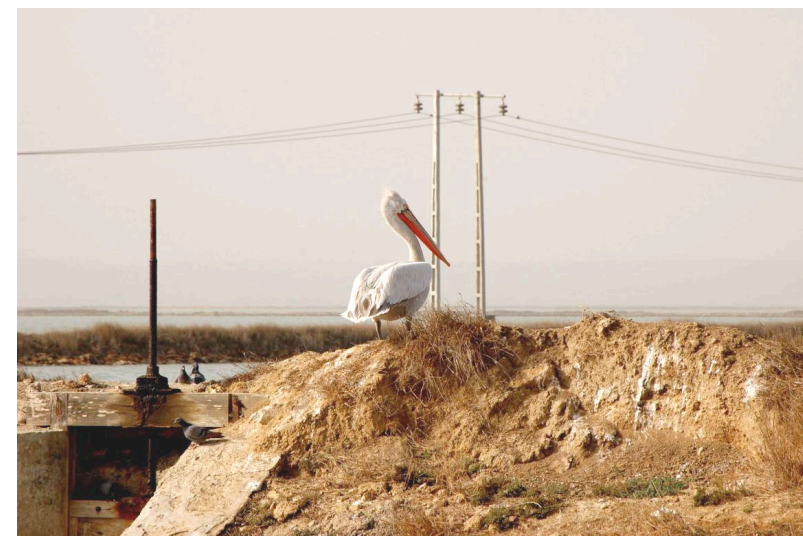

Image 6. Dalmatian Pelican at high risk of collision at salt pans.

BirdLife International 2008b) feeding in the salt pans are also at high risk of collision (Image 6). A large number of flamingos were killed as they got stuck in the electric and barbed wires during the cyclone, which hit Kandla Port in June 1998 (Jaidev Nansey pers. comm.).

The feeding grounds at the salt pan areas of Bhavnagar and Jamnagar districts are high risk zones. The salt pans of Bhavnagar, Charakala and Narara, are wide spread areas and are some of the most preferred feeding habitats of flamingos (Tere 2005). Since salt pans remain inundated throughout the year, the flamingos are constantly exposed to high risk of collision at these sites. There are large numbers of salt pans along the southern coast of the Gulf of Kachchh. The Charakala salt pan is a very large unit and is known to hold huge numbers of flamingos and other waterbirds (Mundkur 1997; Parasharya \& Mukherjee 1998; Jadhav \& Parasharya 2004; Tere \& Parasharya 2005; Jadhav et al. 2005; Islam \& Rahmani 2004, 2008). Though a single incidence of mortality was recorded during the study period (Table 1), the flamingos casualty due to collision with the electric line is a regular phenomenon at the salt pans of Charakala and Narara (Jummabhai Moria pers. comm.). Since, Narara and Charakala salt pans adjoin the Marine National Park, the mortality of flamingos and other waterbirds due to collision with power lines should be considered a matter of serious concern. Besides these two, there are a large number of salt pans all along the Marine National Park on the Jamnagar coast with a potential of bird collisions with the power lines. Therefore special efforts need to be taken to minimize such bird mortality around protected areas.
There is vast area in the Rann as well as the Gulf of Kachchh and the Gulf of Khambhat (particularly the salt pans), where there is an extensive network of power lines, but the area is rarely visited by birdwatchers. Hence, incidences of bird collision with utility structures in these parts of Gujarat have remained unnoticed. The flamingos visiting the Rann of Kachchh (breeding site) during their breeding season are exposed to such wires only for a short period of the year (during inundation), however, at other feeding sites such as salt pans and the sewage ponds of urban areas like Bhavnagar they continuously face the risk of collision as they spend more time there.

Compared to the large population of flamingos and different factors causing mortality (Tere 2005), the mortality caused by collision is low. The species vulnerable to power line collisions are generally long living and slow reproducing under natural conditions. Species such as flamingos require very specific conditions for breeding, resulting in very few successful breeding attempts, or breeding might be restricted to very small areas. These species have not evolved to cope with high adult mortality, with the result that consistent high adult mortality over an extended period could have a serious effect on a population's ability to sustain itself in the long or even medium term (Janss \& Ferrer 1998; Sundar \& Choudhury 2005). Hence, bird deaths due to collision with utility structures at temporary and permanent sites should not be neglected and management plans are required to reduce these threats. The casualty due to collision with utility structures recorded here are only casual records made from the road side and not the result of any systematic/intentional survey. If a systematic survey is done, more sites can be identified where the collision of birds occurs frequently. The majority of power lines are located in remote areas far from public awareness of the bird collision or electrocution problem. In general, reported losses must be considered a superficial measure of collision and electrocution occurrence (Thompson 1978; Longridge 1986; Faanes 1987; Bevanger 1993).

The Lesser Flamingo is threatened largely due to the declining population, very few breeding sites and low reproductive rate. The species is listed in columns $\mathrm{A}$ and $\mathrm{B}$ of the Agreement on the Conservation of AfricanEurasian Migratory Waterbirds (AEWA) Action Plan, Appendix II of the Bonn Convention (CMS) and 
Appendix II of the CITES convention (Childress et al. 2008). For this reason only, the 'International Single Species Action Plan for the Conservation of the Lesser Flamingo Phoeniconaias minor' has come into existence (Childress et al. 2008). Though, India is not a signatory to AEWA, India is certainly a signatory to several other international conservation treaties like CBD, CITES, CMS, Ramsar etc. India holds the fourth largest population of Lesser Flamingos in the world (Childress et al. 2008) and one of the four regular breeding sites (Parasharya \& Tere 2006). Hence it would be the right time to take appropriate mitigation actions to reduce the mortality of flamingos due to collision with electric lines at high risk areas and the areas where new electric transmission lines are to be installed for development. Mitigating measures will also help reduce collision induced mortality in several other waterbird species.

A part of the area of Wild Ass Sanctuary (Little Rann of Kachchh, Gujarat) has been denotified by the government for granting permission for the installation of electric transmission lines by private companies. Special mitigation action should be taken to reduce the risk of waterbird (particularly flamingos) collision, including diversion of the route as it will pass through the high risk wetland zone, both within and outside the protected area.

Considering the large number of salt pans spread over $>1600 \mathrm{~km}$ long coast line of Gujarat State and the network of electric/telephone lines passing through, flamingo and other bird mortality due to collision with utility structures could be much higher than what is documented in this study. Therefore, it is necessary to find appropriate options and take necessary measures to minimize collision of flamingos and other waterbirds in such sensitive habitats. The following options may be considered:

1. Technical modifications of utility structures may contribute in regulating the collisions. One such option is to wrap wires with colored radium tags, at least in collision sensitive areas. This would make the wires visible during day time and shine during the night hours also. Hence, a marking device could limit the collision threat by improving visibility.

2. The power lines can be removed from the sites of frequent collisions and the route can be altered and underground cables can be laid. Maintaining critical distance between the wires and the areas inhabited by birds can also work. An electric distribution line was diverted from the area of Porbandar Bird Sanctuary after the death of 20 Greater Flamingos during 1980s (Kishor Joshi pers. comm.).

3. Research and monitoring should be implemented by state/central governments and the electricity companies, in consultation with relevant experts, to improve our understanding of the impact of electricity transmission installations. The results of research should be made public by publishing in international/ national journals to ensure wider dissemination. This would help in creating awareness among the general public and decision makers.

4. An avian interaction with utility structures is a typical area where biologists and engineers can meet (Bevanger 1990). Engineers in cooperation with biologists have performed a good job identifying electrocution "hot spots" and modifying electrical equipment to avoid or reduce the electrocution and collision in other countries (Olendorff et al. 1981). In India too, a cooperative effort is needed by biologists, authorities within the state forest department, electricity board engineers and to reduce mortality of birds due to collision with utility structures.

5. A further detailed case study can be done to evaluate examples of conflict resolution, case law, or trends in casework.

\section{CONCLUSION}

The cumulative effects of power lines and other sources of unnatural mortality might only manifest itself decades later, when it might be too late to reverse the trend. It is therefore imperative to reduce any form of unnatural mortality of these species, regardless of how insignificant it might seem at the present time. Corrective measures at existing high risk zones and potential collision zones are suggested for the conservation of this Near Threatened species.

\section{REFERENCES}

Ali, S. (1960). "Flamingo City" re-visited: Nesting of the Rosy Pelican (Pelecanus onocrotalus Linnaeus) in the Rann of Kutch. Journal of the Bombay Natural History Society 57: 412-415.

Ali, S. (1974). Breeding of the Lesser Flamingo, Phoeniconaias 
minor (Geofroy) in Kutch. Journal of the Bombay Natural History Society 71(1): 141-144.

Ali, S. \& S.D. Ripley (1983). Handbook of the Birds of India and Pakistan (Compact Edition). Oxford University Press, Delhi, 737pp.

Beaulaurier, D.L. (1981). Mitigation of Bird Collisions with Transmission Lines. Bonneville Power Admin., Portland, Oregon, 82pp.

Bevanger, K. (1990). Topographic aspects of transmission wire collision hazards to game birds in the Central Norwegian coniferous forest. Fauna of Norway Series C, Cinclus 13: 11-18.

Bevanger, K. (1993). Avian interactions with utility structures: A biological approach. $\mathrm{PhD}$ Thesis submitted to University of Trondheim, Norway.

BirdLife International (2008a). Phoeniconaias minor. In: IUCN 2010. IUCN Red List of Threatened Species. Version 2010.4. <www.iucnredlist.org>. Downloaded on 03 June 2011.

BirdLife International (2008b). Pelecanus crispus. In: IUCN 2010. IUCN Red List of Threatened Species. Version 2010.4. $<$ www.iucnredlist.org>. Downloaded on 03 June 2011.

Brown, W.M. (1993). Avian collisions with utility structures: biological perspectives. pp. 1-13 (12). In: Colson, E. \& J.W. Huckabee (eds.) Proceedings of International Workshop on Avian Interactions with Utility Structures. Electric Power Research Committee and Avian Power Line Interactions Committee, Palo Alto, California.

Childress, B., S. Nagy \& B. Huges (Compilers) (2008). International Single Species Action Plan for the Conservation of the Lesser Flamingo (Phoeniconaias minor). CMS Technical Series No. 18. AEWA Technical Series No. 34. Bonn, Germany.

Crivelli, A.J., H. Jerrentrup, \& T. Mitchew (1988). Electric power lines: a cause of mortality in Pelecanus crispus Bruch, a world endangered bird species. Colonial Waterbirds 11: 301-305.

Faanes, C.A. (1987). Bird behavior and mortality in relation to power lines in prairie habitats. U.S. Fish and Wildlife Service Technical Report 7, 1-24pp.

Hugie, R.D., J.M. Bridges, B.S. Chanson \& M. Skougard (1993). Results of a post construction bird monitoring study on the Great Falls-Conrad transmission line, 21(6): 1-21. In: Colson, E. \& J.W. Huckabee (eds.). Proceedings of International Workshop on Avian Interactions with Utility Structures. Electric Power Research Committee and Avian Power Line Interactions Committee, Palo Alto, California.

Islam, M.Z. \& A.R. Rahmani (2004). Important Bird Areas in India. Indian Bird Conservation Network: Bombay Natural History Society and Bird Life International (U. K.) Oxford University Press, xviii+1133pp.

Islam, M.Z. \& A.R. Rahmani (2008). Potential and Existing Ramsar Sites in India. Indian Bird Conservation Network: Bombay Natural History Society, Bird Life International and Royal Society for the Protection of Birds. Oxford University Press, 592pp.
Jadhav, A. \& B.M. Parasharya (2004). Counts of flamingos at some sites in Gujarat State, India. Waterbirds 27(2): 141-146.

Jadhav, A., B.M. Parasharya \& B. Rughani (2005). Charakala saltpans: A heaven for Black-necked Grebe Podiceps nigricollis Brehm. Journal of the Bombay Natural History Society 102 (2): 228-229.

Janss, G.F.E. \& M. Ferrer (1998). Rate of Bird collision with power lines: effects of conductor-marking and static wiremarking. Journal of Field Ornithology 69(1): 8-17.

Johnson, A. \& F. Cezilly (2007). The Greater Flamingo. A. \& C. Black Publishers Ltd. London, 328pp.

Longridge, M.W. (1986). The impact of transmission lines on bird flight behaviour, with reference to collision mortality and systems reliability. Bird Research Committee Report. Electricity Supply Commission (ESCOM), Johannesburg. Report: 1-279.

Mc Cann, K. \& C. van Rooyen (2002). Wildlife / Powerline interactions, pp. 23-29. In: Anon. (ed). Proceedings of the $14^{\text {th }}$ South African Crane Working Group Workshop: 18-20 March 2002, South Africa: South African Crane Working Group.

McNeil, R., S.J.R. Rodrignez \& H. Ouellet (1985). Bird mortality at a power transmission line in northwestern Venezuela. Biological Conservation 31: 153-165.

Morkill, A.E. \& S.H. Anderson (1991). Effectiveness of marking power lines to reduce Sandhill Crane collisions. Wildlife Society Bulletin 19: 442-449.

Mukherjee, A., C.K. Borad \& B.M. Parasharya (2002). A study of the ecological requirements of waterfowl at manmade reservoirs in Kheda district, Gujarat, India with a view towards conservation, management and planning. Zoos' Print Journal 17(5): 775-785.

Mundkur, T. (1997). The Lesser Flamingo - A summary of its current distribution and conservation in Asia, pp. 62-69. In: Howard, G. W. (ed.). Conservation of the Lesser Flamingo in Eastern Africa and Beyond. Proceedings of a Workshop at Lake Bogoria, Kenya, 26-29 August 1997. IUCN Eastern Africa Regional Programme, 120pp.

Ogilvie, M. \& C. Ogilvie (1986). Flamingos. Allan Sutton Publishing Limited, Gloucester, U.K., 121pp.

Olendorff, R.R., A.D. Miller \& R.N. Lehman (1981). Suggested practices for raptor protection on power linesThe state of the art in 1981. Raptor Research Foundation, Inc., Raptor Research Report No. 4., St. Paul, Minnesota. $111 \mathrm{pp}$.

Parasharya, B.M. \& A. Mukherjee (1998). A record number of Blacknecked Grebe Podiceps nigricollis from Gujarat. Journal of the Bombay Natural History Society 95: 335336.

Parasharya, B.M., K.L. Mathew \& D.N. Yadav (2000). Population estimation and general ecology of the Indian Sarus Crane Grus antigone antigone in Kheda district, Gujarat. Pavo 38 (1\&2): 25-34.

Parasharya, B.M. \& A. Tere (2006). Lesser Flamingos in India: A Knowledge Update. Anand Agricultural University, 
Anand, 23pp.

Sundar, K.S.G. \& B.C. Choudhury (2005). Mortality of Sarus Cranes (Grus antigone) due to electricity wires in Uttar Pradesh, India. Environmental Conservation 32(3): 260-69.

Tere, A. \& B.M. Parasharya (2005). Post-breeding distribution of flamingos and their population estimation. Flamingo, Newsletter of the Bird Conservation Society, Gujarat 3(4): 2-5.

Tere, A. (2005). Ecology of Greater Flamingo Phoenicopterus roseus and Lesser Flamingo Phoenicopterus minor on wetlands of Gujarat. PhD Thesis submitted to the Maharaja Sayajirao University of Baroda, Gujarat, India.

Thompson, L.S. (1978). Transmission line wire strikes: mitigation through engineering design and habitat modification, pp. 51-92. In: Avery, M.J. (ed.) Impact of Transmission Lines on Birds in Flight. Proceedings of a Conference, Oak Ridge Associated Universities, Oak Ridge, Tennessee.
Author Details: Dr. ANIKA TERE has worked on 'Ecology of Greater Flamingo Phoenicopterus roseus and Lesser Flamingo Phoenicopterus minor on wetlands of Gujarat' during 2002 to 2005 and earned her PhD Thesis from the Maharaja Sayajirao University of Baroda, Gujarat, India. Besides flamingos, she has interest in avian ecology, wetland ecology and faunal diversity inventory in general. At present she is a lecturer at M.S. University of Baroda, Vadodara. She has also contributed to the formulation of Global Conservation Action Plan for Lesser Flamingos.

Dr. B. M. PARAsharya is a field ornithologist. He worked on the ecology of Western Reef Heron and other coastal birds for his doctorate degree and earned the same from Saurashtra University in 1984. At Anand Agricultural University, focus of his research is management of crop depredatory birds, insect \& rodent predators and conservation of birds in agricultural landscape. Besides research and teaching, he has also guided students in areas like avian ecology as well as spider and butterfly diversity. $\mathrm{He}$ has done pioneering work on the ecology of Western Reef Heron, Indian Sarus Crane and Lesser Flamingo. He has also contributed to the formulation of Global Conservation Action Plan for Lesser Flamingos. He has special interest in wetland ecology. 